\title{
Procedural Review by the ECtHR: A Typology
}

\author{
JANNEKE GERARDS
}

\subsection{Introduction}

The European Court of Human Rights (ECtHR) has often emphasised the importance of substantive reasonableness review of limitations of Convention rights. It has held that ' $\ldots$ inherent in the whole of the Convention is a search for a fair balance between the demands of the general interest of the community and the requirements of the protection of the individual's fundamental rights. ${ }^{1}$ Indeed, it can be seen that the Court often evaluates the substance of the arguments that have been exchanged before the national courts or in the national legislative process, and it assesses whether these arguments can serve to justify an interference with a Convention right. Regardless of the overriding importance of proportionality review and balancing to the Court's argumentation, it is equally clear that, over the past years, the Court increasingly has taken a procedural turn. ${ }^{2}$ This is especially manifest in its case law related to positive obligations, which often are procedural in nature. ${ }^{3}$ It is wellknown, for example, that the Court has identified self-standing procedural

${ }^{1}$ Soering v. the United Kingdom, ECtHR 7 July 1988, no. 14038/88, para. 89.

2 See more elaborately already e.g. O. De Schutter and F. Tulkens, 'Rights in Conflict: The European Court of Human Rights as a Pragmatic Institution', in E. Brems, Conflicts between Fundamental Rights (Antwerp, Intersentia 2008) pp. 169-216 at p. 208ff; P. Popelier, 'The Court as Regulatory Watchdog: The Procedural Approach in the Case Law of the European Court of Human Rights', in P. Popelier et al (eds), The Role of Constitutional Courts in Multilevel Governance (Antwerp, Intersentia 2012) pp. 249-268; P. Popelier and C. Van de Heyning, 'Procedural Rationality: Giving Teeth to the Proportionality Analysis', 9 European Constitutional Law Review (2013) pp. 230-262; J.H. Gerards, 'The European Court of Human Rights and the National Courts-Giving Shape to the Notion of 'Shared Responsibility', in J.H. Gerards and J.W.A. Fleuren (eds), Implementation of the European Convention on Human Rights and of the Judgments of the ECtHR in National Case Law. A Comparative Analysis (Antwerp, Intersentia) pp. 13-94; A. Kavanagh, 'Proportionality and Parliamentary Debates: Exploring Some Forbidden Territory', 34 Oxford Journal of Legal Studies (2014) pp. 443-479.

${ }^{3}$ See in more detail hereafter, section 6.2. 
obligations in relation to Articles 2 and 3 of the Convention, compelling the States to conduct prompt, adequate and effective investigations into alleged cases of ill-treatment or suspicious deaths. The Court has found a wide range of procedural obligations in relation to other Convention articles, too, varying from obligations to protect against arbitrariness in house searches to obligations to provide for careful national review of restrictions of use of property.

Next to the development of procedural positive obligations, another development in the Court's approach can be noted that discloses a stronger emphasis on procedural aspects. It can be seen in various cases that the Court is no longer only looking at the reasonableness of the balance struck by the national authorities, but instead (or in addition to this) focuses on the fairness and due care taken in the national procedures leading up to a limitation. ${ }^{4}$ In relation to cases concerning conflicts between the right to respect for one's private life and the freedom of expression, the Court even has expressly mentioned that 'where the balancing exercise has been undertaken by the national authorities in conformity with the criteria laid down in the Court's case law, the Court would require strong reasons to substitute its view for that of the domestic courts'. ${ }^{5}$ In these cases, the Court does not intend to 're-balance' the interests at stake to arrive at a conclusion of its own on the reasonableness of a certain limitation of a fundamental right. ${ }^{6}$ Instead, it mainly reviews whether the national courts have sufficiently carefully applied the Convention standards and if they have made an adequate effort to identify and balance all relevant interests. If so, the Court can relatively easily accept the decision the national court has made without paying much attention to its contents and the substance of its justification. ${ }^{7}$

Although it is widely agreed that elements of procedural review are increasingly common in the Court's case law, ${ }^{8}$ and the Court itself has

${ }^{4}$ For further analyses of these developments, see the sources mentioned supra, n. 2.

5 Von Hannover (No. 2) v. Germany, ECtHR 7 February 2012, nos. 40660/08 and 60641/08, para. 107.

${ }^{6}$ Cf. Popelier 2012, supra n. 2, p. 252 and 257; Gerards, supra n. 2, pp. $52 \mathrm{ff}$.

7 Indeed, in a background document prepared for the opening of the judicial year 2015, a few judges of the ECtHR have expressly mentioned this approach; see Seminar to Mark the Opening of the Judicial Year 2015-Subsidiarity: A Two-Sided Coin?, Background paper prepared by the organising committee, www.echr.coe.int/Documents/Seminar_ background_paper_2015_ENG.pdf, paras. 34ff.

${ }^{8}$ See the various sources mentioned in Chapter 1 of this volume and see Chapter 2 by Eva Brems ('The "Logics" of Procedural-Type Review by the European Court of Human 
stressed the importance of this, ${ }^{9}$ as yet, there is not much clarity as regards the types of procedural review it conducts and the function of procedural review for its substantive examination of limitations. ${ }^{10}$ Is this limited to the drawing of positive or negative inferences from national procedures? Or can 'procedural review' be defined more broadly?

Against that background, this chapter aims to provide for a typology of procedural review as it can currently be found in the case law of the ECtHR. ${ }^{11}$ The typology presented is based on a distinction between two main aspects of the Court's 'procedural turn', i.e. (1) setting positive obligations of a procedural nature or improving the legitimacy of national procedures; and (2) relying on the quality of national decisionmaking in the review of justifications for interferences with Convention rights. It is submitted that these two aspects are closely connected, to the extent that procedural review of the second type, i.e. review that takes account of the quality of the national decision-making process, is often based on the degree to which states have acted in conformity with their procedural positive obligations. Because of this interconnectedness, this chapter first presents a brief review of different types of procedural positive obligations the Court has developed in its case law, with the objective of clarifying the benchmark of procedural requirements that need to be taken into account by national legislators and by administrative and judicial bodies (section 6.2). Subsequently, the chapter looks into the ways in which the Court has woven procedural elements into its substantive reasonableness review. Here, attention is paid to the Court's tendency to pay attention to the quality of national legislative debates underlying limitations to the exercise of Convention rights (section 6.3). An endeavour is made to identify different situation types in

Rights') and Chapter 7 by Angelika Nussberger ('Procedural Review by the European Court of Human Rights: View from the Court').

9 See Contribution of the Court to the Brussels Conference, 26 January 2015 (www.echr.coe .int/Documents/2015_Brussels_Conference_Contribution_Court_ENG.pdf), para. 6 and cf. R. Spano, 'Universality or Diversity of Human Rights? Strasbourg in the Age of Subsidiarity', 14 Human Rights Law Review (2014) pp. 487-502 at p. 498.

10 Although some analyses have been made in scholarly literature (see supra n. 2), they are far from comprehensive and mainly aim at giving examples as a basis for criticising or embracing the Court's procedural approach.

11 Different typologies from the one presented here are, of course, conceivable. Popelier, for instance, has categorised the case law according to the type of regulative instruments and the nature of the debates the Court takes into account (2012, supra n. 2, pp. 258ff), but she focuses on review of legislation only. Since the present chapter also analyses case law on national judicial and administrative decision-making, it seemed less suitable to follow-up on this particular typology. 
which the Court relies on this argument in its case law, as well as to provide some clarity as to the actual impact of this type of argument on the Court's reasoning. The Court's review of the procedural fairness and quality of national judicial procedures is discussed next (section 6.4). Again, the objective is to investigate in which types of cases and to what effect the Court uses elements of procedural review. The typology presented in these two sections is based on an analysis of judgments and decisions of the Court's Chambers and Grand Chamber in the period 1 January 2012 up until 1 January 2015. The sample of judgments is based on their 'importance level' (selecting mainly level 1 and 2 cases) ${ }^{12}$ and on their potential for a certain degree of procedural review. ${ }^{13}$

The final section of this chapter (section 6.5) aims to distil some common principles from the typology and analysis presented in sections 6.2-6.4. After summarising the current function of procedural review for the Court's case law, it discusses whether the use of procedural elements is consistent and it highlights some challenges for the future. By doing so, this section aims to provide a baseline for further development of techniques of procedural review by the Court, as well as for further debate on the legitimacy and acceptability of these techniques.

\subsection{Procedural Requirements under the Convention}

\subsubsection{Introduction}

The Court's procedural obligations case law has been analysed extensively in legal scholarship. In particular, important reviews have been provided of the various obligations developed in relation to the different articles of the Convention. ${ }^{14}$ This chapter does not intend to duplicate such analyses, but it aims to build on them by identifying some general

12 The 'importance level' system is explained in the Court's HUDOC database, www.hudoc .echr.coe.int; see also e.g. Annual Report 2012, Short Survey of the Main Judgments and Decisions Delivered by the Court in 2012, www.echr.coe.int/Documents/ Short_Survey_2012_ENG.pdf, footnote 2 .

13 The selection of cases is on file with the author.

14 See in particular E. Brems, 'Procedural Protection: An Examination of Procedural Safeguards Read into Substantive Convention Rights', in E. Brems and J.H. Gerards (eds), Shaping Rights in the ECHR. The Role of the European Court of Human Rights in Determining the Scope of Human Rights (Cambridge, Cambridge University Press 2014) pp. 137-161; E. Brems and L. Lavrysen, 'Procedural Justice in Human Rights Adjudication: The European Court of Human Rights', 35 Human Rights Quarterly (2013) pp. 176-200; C. Dröge, Positive Verpflichtungen der Staaten in der Europäischen Menschenrechtskonvention [Positive Obligations of the States in the European Convention of Human Rights] (Berlin, Springer 
requirements for national legislation, national decision-making and national judicial procedures. This section thereby focuses on the procedural requirements that are of direct relevance to the second aspect of the Court's procedural turn, i.e. its tendency to pay attention to the fairness and quality of national decision-making procedures in its review of the reasonableness of limitations. It is important to stress that a rather wide understanding of 'procedural' positive obligations is used here, in the sense that also obligations related to the overall legitimacy of the legislative process are considered, such as obligations which directly contribute to deliberation and participation in legislative debates.

\subsubsection{Legislation}

The Court has been reluctant to define strict requirements to be met by national legislative processes. Legislation is the domain of national constitutional law and the Court, reasoning from its subsidiary position as a supranational court, does not regard it as its task to set specific obviously constitutional obligations for the States. ${ }^{15}$ Moreover, the Court has generally refrained from formulating very clear and specific obligations related to the quality of legislation which are closely related to theories of 'better regulation'. ${ }^{16}$ Although sometimes the Court has reproached national legislatures for not having taken sufficient care in preparing legislation, or rather commended them for the quality of their work (as will be discussed in section 6.3), it has not (yet) translated this into clear and concrete positive obligations to be met by all the States Parties. ${ }^{17}$ Nevertheless, it has defined a number of more general requirements based on the principles of democracy, pluralism and the rule of law

2003); D. Xenos, The Positive Obligations of the State under the European Convention of Human Rights (London, Routledge 2012).

15 Cf. e.g. McGonnell v. the United Kingdom, ECtHR 8 February 2000, no. 28488/95, para. 51; Kleyn and Others v. the Netherlands, ECtHR (GC) 6 May 2003, nos. 39343/98 et al., para. 193; Sindicatul 'Pastorul Cel Bun'v. Romania, ECtHR (GC) 9 July 2013, no. 2330/09, paras. 156-157. See also, more elaborately, D. Kosař, 'Policing Separation of Powers: A New Role for the European Court of Human Rights?', 8 European Constitutional Law Review (2012) pp. 33-62 and H.M. ten Napel, 'The European Court of Human Rights and Political Rights: The Need for More Guidance', 5 European Constitutional Law Review (2009) pp. 464-480. Cf. further Popelier 2012, supra n. 2, p. 257.

${ }^{16}$ See in more detail Chapter 4 in this volume by Patricia Popelier: Evidence-Based Lawmaking: Influences, Obstacles and the Role of the European Court of Human Rights.

17 It is not unlikely that this will happen in the future, given that in a recent policy document, the Court itself has stressed the importance of 'national parliaments to give careful consideration to the human rights issues that arise in the course of adopting legislation' 
that may be seen to relate to the legitimacy and quality of the legislative process. ${ }^{18}$ These requirements are closely connected to notions of deliberative democracy and they aim to incentivise the deliberative process in national legal orders. ${ }^{19}$

Generally, for example, the Court has embraced the general notion of rule of law and it has translated this into some concrete obligations and requirements for the States. ${ }^{20}$ It may be recalled, for example, that the Court has formulated a number of rather detailed requirements related to legal certainty, such as requirements of forseeability and accessibility of legislation. ${ }^{21}$ In other judgments, it has expressed that there is a need for safeguards to avoid arbitrariness and enhance transparency and predictability. ${ }^{22}$

The Court has also formulated a number of general requirements related to the quality of the underlying processes of and procedures for parliamentary deliberation and societal debate. ${ }^{23}$ For example, the Court has defined a number of requirements in relation to Article 3 of Protocol No. 1 to the Convention relating to the openness and quality of parliamentary elections. ${ }^{24}$ In this context, the Court has held, inter alia, that fair and equal participation in elections must be guaranteed in order to ensure good representation in legislative bodies. ${ }^{25}$ More generally, the

(Contribution of the Court to the Brussels Conference, 26 January 2015, www.echr.coe .int/Documents/2015_Brussels_Conference_Contribution_Court_ENG.pdf).

18 See expressly Golder v. the United Kingdom, ECtHR 21 February 1975, no. 4451/70, para. 34.

19 On the relevance and importance of deliberative democracy for procedural review, see further Chapter 3 by Aruna Sathanapally in this volume: The Modest Promise of 'Procedural Review' in Fundamental Rights Cases.

${ }^{20}$ E.g. McGonnell v. the United Kingdom, ECtHR 8 February 2000, no. 28488/95; Stafford v. the United Kingdom, ECtHR 28 May 2002, no. 46295/99, para. 78; Benjamin and Wilson v. the United Kingdom, ECtHR 26 September 2002, no. 28212/95, para. 36; cf. also Kosar,, supra n. 15.

${ }^{21}$ Classically in Sunday Times v. the United Kingdom, ECtHR 26 April 1979, no. 6538/74, para. 49. For the need to provide for clear legislation, see also e.g. Gross v. Switzerland, ECtHR 14 May 2013, no. 67810/10.

22 E.g. Malone v. the United Kingdom, ECtHR 2 August 1984, no. 8691/79, para. 68; P.G. and J.H. v. the United Kingdom, ECtHR 25 September 2001, no. 44787/98, para. 63; Assanidze v. Georgia, ECtHR (GC) 8 April 2004, no. $71503 / 01$ paras. 173 and 175; Golovan v. Ukraine, ECtHR 5 July 2012, no. 41716/06; L.H. v. Latvia, ECtHR 29 April 2014, no. 52019/07. See also Popelier 2012, supra n. 2, p. 253.

${ }^{23}$ See also Popelier 2012, supra n. 2, p. 256.

${ }^{24}$ On the general principles and obligations following from Article 3 P1, see e.g. Hirst (No. 2) v. the United Kingdom, ECtHR (GC) 6 October 2005, no. 74025/01.

25 See e.g. Mathieu Mohin and Clerfayt v. Belgium, ECtHR 2 March 1987, no. 9267/81; Yumak and Sadak v. Turkey, ECtHR (GC) 8 July 2008, no. 10226/03; Tanase v. Moldova, 
Court has emphasised the obligation of the States Parties to safeguard free exchange of ideas and to create an atmosphere in which there is room for public debate on topics of general interest. It is the States' task to guarantee media pluralism and to make sure everyone has adequate access to information. ${ }^{26}$ The Court has also emphasised that freedom of expression is especially important for elected representatives of the people. ${ }^{27}$ Parliamentarians must be able to draw attention to the people's preoccupations and defend their interests, and more generally, parliaments or comparable bodies are considered to constitute essential fora for political debate. ${ }^{28}$ The Court highly values the existence of actual and explicit debate in the legislative bodies, as well as in general society, and it deems it crucial that there is sufficient openness to discuss all relevant issues and present all thinkable arguments and information. ${ }^{29}$

The States must further guarantee that no groups or minorities are unwarrantedly excluded from the process of decision-making and legislation, either de iure or de facto. ${ }^{30}$ If certain groups historically have been placed in a disadvantageous position and their voice remains unheard because of negative stereotyping and stigmatisation, special attention must be paid to their representation and participation in the public debate. ${ }^{31}$ More generally, the equality of all human beings before the law must be respected as a basic principle of the rule of law. ${ }^{32}$

Finally, it may be mentioned that it is considered unacceptable if legislation is overbroad or over-inclusive, excluding a large and indeterminate group from exercising a fundamental right, ${ }^{33}$ or strongly

ECtHR (GC), 27 April 2010, no. 7/08; Sitaropoulos and Giakomopoulos v. Greece, ECtHR (GC) 15 March 2012, no. 42202/07.

26 E.g. Manole and Others v. Moldova, ECtHR 17 September 2009, no. 13936/02, paras. 100 and 107; Frasila and Ciocirlan v. Romenia, ECtHR 10 May 2012, no. 25329/03; Centro Europa 7 S.r.l. and Di Stefano v. Italy, ECtHR 7 June 2012, no. 38433/09.

${ }_{27}$ Karácsony and Others v. Hungary, ECtHR 16 September 2014, no. 42461/13, para. 66.

28 Ibid.

29 This is particularly clear from the prisoners' voting rights cases; see especially Hirst (No. 2) v. the United Kingdom, ECtHR (GC) 6 October 2005, no. 74025/01. See also Popelier 2012, supra n. 2.

${ }^{30}$ Cf. Popelier 2012, supra n. 2, pp. 255 and 264ff.

31 Alajos Kiss v. Hungary, ECtHR 20 May 2010, no. 38832/06.

${ }^{32}$ Refah Partisi v. Turkey, ECtHR 31 July 2001, no. 41340/98, para. 43.

33 See also A. Stone Sweet, 'The European Convention on Human Rights and National Constitutional Reordering', 33 Cardozo Law Review (2012) pp. 1859-1868 at p. 1863. For a few examples, see Dickson v. the United Kingdom, ECtHR (GC) 4 December 2007, no. 44362/04; Kubaszewski v. Poland, ECtHR 2 February 2010, no. 571/04; M.D. and others v. Malta, ECtHR 17 July 2012, no. 64791/10; Godelli v. Italy, ECtHR 25 September 2012, no. 33783/09. 
restricting the possibilities for individualised application or review. ${ }^{34,35}$ The flipside of this is that there is a general presumption or even a requirement that there should always be room for individualised (judicial) decision-making. ${ }^{36}$ In particular, in some cases regarding the exclusion of prisoners from the right to vote, the Court for some time appeared to require individual court judgments in each and every case of prisoner disenfranchisement, rather than the application of a general rule, even if such a general rule differentiated between groups of prisoners according to the type of offence or the duration of their sentences. ${ }^{37}$ Also in the area of family law, ${ }^{38}$ the Court has stressed time and again that legislative presumptions are problematic and should be replaced by particularised judicial decision-making. ${ }^{39}$ Similarly, a system of lifetime sentences without possibility of interim review of the reasons for continued detention cannot be squared with the obligations under Article 3 $\mathrm{ECHR},{ }^{40}$ and the same goes for 'blanket and indiscriminate' limitations of the freedom of movement. ${ }^{41}$ Nevertheless, it is important to put this case law into perspective, since the Court does not always require individualisation and may be inclined to accept general measures and blanket bans. ${ }^{42}$ Exceptions to this general presumption are visible mainly in those cases where moral issues are at stake and legal certainty would seem to prevail over individual justice, ${ }^{43}$ as well as in cases concerning social

34 E.g. Ricci v. Italy, ECtHR 8 October 2013, no. 30210/06; Nusret Kaya and Others v. Turkey, ECtHR 22 April 2014, nos. 43750/06 et al; Paulet v. the United Kingdom, ECtHR 13 May 2014, no. 6219/08; Gablishvili v. Russia, ECtHR 26 June 2014, no. 39428/12.

35 Or both, see e.g. Söyler v. Turkey, ECtHR 17 September 2013, no. 29411/07. See also Popelier 2012, supra n. 2, p. 256 and Gerards, supra n. 2.

${ }^{36}$ Or rather, as Sales and Hooper have held, 'fact sensitive' laws are preferred over 'fact insensitive laws'; P. Sales and B. Hooper, 'Proportionality and the Form of Law', 119 Law Quarterly Review (2003) pp. 426-454, p. 429.

37 E.g. Frödl v. Austria, ECtHR 8 April 2010, no. 20201/04, paras. 33-34; see also Anchugov and Gladkov v. Russia, ECtHR 4 July 2013, nos. 11157/04 and 15162/05.

38 But certainly not limited to that; see e.g. Bjedov v. Croatia, ECtHR 29 May 2012, no. $42150 / 09$, concerning the occupation of a social tenancy flat.

39 E.g. Ādamsons v. Latvia, ECtHR 24 June 2008, no. 3669/03; Schneider v. Germany, ECtHR 15 September 2011, no. 17080/07, para. 100; C.A.S. and C.S. v. Romania, ECtHR 20 March 2012, no. 26692/05; M.D. and Others v. Malta, ECtHR 17 July 2012, no. 64791/10; Godelli v. Italy, ECtHR 25 September 2012, no. 33783/09.

40 See in particular Vinter v. the United Kingdom, ECtHR (GC) 9 July 2012, nos. 66069/09, $130 / 10$ and 3896/10, paras. 119-122.

${ }^{41}$ E.g. Stamose v. Bulgaria, ECtHR 27 November 2012, no. 29713/05, para. 34.

${ }^{42}$ See more elaborately Sales and Hooper, supra n. 36, p. 440 and Gerards, supra n. 2, pp. 59ff.

43 See e.g. Evans v. the United Kingdom, ECtHR (GC) 10 April 2007, no. 6339/05; in this case, it turned out that all decisions that could be taken in an individual cases would harm the interests of another individual, making general legislation just as arbitrary as individual 
security and planning issues. ${ }^{44}$ Also in one of the voting rights cases, the Court's Grand Chamber has mentioned in general terms that the intervention of a judge is not always necessary, holding that 'the Contracting States may decide either to leave it to the courts to determine the proportionality of a measure restricting convicted prisoners' voting rights, or to incorporate provisions into their laws defining the circumstances in which such a measure should be applied. In this latter case, it will be for the legislature itself to balance the competing interests in order to avoid any general, automatic and indiscriminate restriction' ${ }^{45}$ In a more recent judgment in Animal Defenders International v. the United Kingdom, the Court's Grand Chamber confirmed this position and further elaborated on it. ${ }^{46}$ In particular, it defined some criteria to determine whether general measures are acceptable or further individualisation can be required. ${ }^{47}$ Clearly, thus, the Court accepts that there may be good reason to adopt a blanket rule that does not allow for (much) individualisation, especially from a perspective of legal certainty. ${ }^{48}$ In the light of this chapter's aims, it is important to note, however, that in one breath, the Grand Chamber also stressed the importance of diligent parliamentary preparation of such general measures. ${ }^{49}$ Moreover, it is clear in many cases the Court still requires a possibility of

decision-making, but more certain and predictable nonetheless; for a similar example, see S.H. and Others v. Austria, ECtHR (GC) 3 November 2011, no. 57813/00; on this, see also Sales and Hooper, supra n. 36, p. 434; J. Bomhoff and L. Zucca, 'The Tragedy of Ms Evans: Conflicts and Incommensurability of Rights', 2 European Constitutional Law Review (2006) p. 424 at pp. 429-430. However, the case law is not entirely consistent here; see e.g. Dickson v. the United Kingdom, ECtHR (GC) 4 December 2007, no. 44362/04.

${ }^{44}$ See e.g. Twizell v. the United Kingdom, ECtHR 20 May 2008, no. 25379/02; Maggio and Others v. Italy, ECtHR 31 May 2011, no. 46286/09 et al. Cf. also already Sales and Hooper, supra n. 36, pp. 432-433.

45 Scoppola (No. 3) v. Italy, ECtHR (GC) 22 May 2012, no. 126/05, para. 102. See similarly Shindler v. the United Kingdom, ECtHR 7 May 2013, no. 19840/09 and, outside the context of voting rights of prisoners, Hristozov and Others v. Bulgaria, ECtHR 13 November 2012, nos. 47039/11 and 358/12, para. 126. Nevertheless, regardless of this nuance, clearly overbroad legislation is not accepted; see e.g. Söyler v. Turkey, ECtHR 17 September 2013, no. 29411/07.

46 Animal Defenders International v. the United Kingdom, ECtHR (GC) 22 April 2013, no. $48876 / 08$.

47 See paras. $108-110$.

${ }^{4}$ See also The National Union of Rail, Maritime and Transport Workers v. the United Kingdom, ECtHR 8 April 2014, no. 31045/10, para. 101-104.

49 See also The National Union of Rail, Maritime and Transport Workers v. the United Kingdom, ECtHR 8 April 2014, no. 31045/10. For a critical note on this approach, see T. Lewis, 'Animal Defenders International v. United Kingdom: Sensible Dialogue or a Bad Case of Strasbourg Jitters?’, 77 Modern Law Review (2014) pp. 460-492 at p. 468. 
individualisation, and it continues to reject automatically and indiscriminately applied legislation. ${ }^{50}$

\subsubsection{Judicial Procedures and Administrative Decision-Making}

\subsubsection{General Overview of Procedural Obligations}

Much has been written on positive obligations and requirements following from the Convention regarding the availability of national judicial remedies and the quality and fairness of national judicial procedures. ${ }^{51}$ Such obligations either follow from dedicated Convention provisions (Article 6 on the right to a fair trial and Article 13 on the right to an effective remedy) or, increasingly, from substantive rights provisions, such as Article 2 (the right to life) or Article 8 (the right to private and family life). In relation to all rights laid down in the Convention, individuals need to be provided with effective access to a judicial remedy to enable them to complain about a lack of protection of their (Convention) rights and interests. ${ }^{52}$ National procedures must be designed so as to guarantee procedural fairness. This does not only mean the obvious, such as guaranteeing that tribunals are established by law, ${ }^{53}$ that judges are independent and impartial, ${ }^{54}$ that proceedings are conducted within a reasonable time, ${ }^{55}$ that adversarial proceedings respecting equality of arms are guaranteed, ${ }^{56}$ that the legislature should not unduly intervene with judicial proceedings ${ }^{57}$ and that final

50 E.g. Ricci v. Italy, ECtHR 8 October 2013, appl. no. 30210/06 and Brunet v. France, ECtHR 18 September 2014, appl. no. 21010/10.

${ }^{51}$ See the sources mentioned supra, n. 14 .

52 Of course, this even is an express requirement laid down in Article 13 of the Convention. See in particular also e.g. Silver and Others v. the United Kingdom, ECtHR 25 March 1983, nos. 5947/72 et al, para. 90; Brogan and Others v. the United Kingdom, ECtHR 29 November 1988, nos. 11209/84 et al, para. 58; Huvig v. France, ECtHR 24 April 1990, no. 11105/84, para. 31; Conka v. Belgium, ECtHR 5 February 2002, no. 51564/99, para. 83.

53 E.g. Kress v. France, ECtHR 7 June 2001, no. 39594/98, para. 69; Lavents v. Latvia, ECtHR 28 November 2001, no. 58442/00, para. 81.

54 E.g. Le Compte, Van Leuven and De Meyere v. Belgium, ECtHR 23 June 1981, nos. 6878/75 and 7238/75, para. 55; Kleyn and Others v. the Netherlands, ECtHR (GC) 6 May 2003, nos. 39343/98 et al; Kyprianou v. Cyprus, ECtHR (GC) 15 December 2005, no. 73797/01.

55 E.g. Ferrari v. Italy, ECtHR (GC) 26 July 1999, no. 33440/96.

56 E.g. Dombo Beheer v. the Netherlands, ECtHR 27 October 1993, no. 14448/88, para. 33; Steel and Morris v. the United Kingdom, ECtHR 15 February 2005, no. 68416/01, paras. 59 and 62; Krcmar and Others v. the Czech Republic, ECtHR 3 March 2000, no. 35376/97, para. 40.

57 E.g. Stran Greek Refineries v. Greece, ECtHR 9 December 1994, no. 13427/87, para. 49. 
judgments are executed promptly and with due care. ${ }^{58,59}$ With a great degree of detail and refinement, the Court has also held that national judgments ought to be adequately reasoned and sufficiently predictable, ${ }^{60}$ that individuals should be granted access to (free or subsidised) legal assistance, ${ }^{61}$ that the parties should be given sufficient time to study the files and to bring evidence, that judges should not blindly rely on the quality of expert opinions, ${ }^{62}$ that solutions should be found to harmonise problematically inconsistent lines of case law ${ }^{63}$ and so on. In addition, as a corollary of the requirement of individualised application discussed in section 6.2.2, the Court may require national courts to review the reasonableness of application of general legislation to the concrete case at hand. ${ }^{64}$

The Court has defined a similar variety of obligations of procedural fairness and procedural due care in relation to administrative decisionmaking. First and foremost, guarantees must be adopted to ascertain that administrative powers are not used in an arbitrary fashion. ${ }^{65}$ Moreover, States have to abide by their own rules, which means that administrative authorities need to apply such rules consistently. ${ }^{66}$ In addition to this, the Court has accepted a variety of more specific procedural positive obligations, which are closely geared to specific situation types. Decisions related to medical treatment, for example, must be reasoned and must

58 E.g. Hornsby v. Greece, ECtHR 19 March 2007, no. 18357/91, para. 40; Brumarescu v. Romania, ECtHR (GC) 28 October 1999, no. 28342/95, para. 61.

59 These requirements generally also follow from Article 6 ECHR; the interrelationship between the procedural positive obligations following from substantive provisions and the requirements following from Article $6 \mathrm{ECHR}$ is a complicated one, however; see e.g. Zagrebačka banka d.d. v. Croatia, ECtHR 12 December 2013, no. 39544/05.

60 E.g. Beian v. Romania, ECtHR 6 December 2007, no. 30658/05, para. 39; Garcia Ruiz v. Spain, ECtHR (GC) 21 January 1999, no. 30544/96, para. 26.

61 Classically in Airey v. Ireland, ECtHR 9 October 1979, no. 6289/73.

62 E.g. Plesó v. Hungary, ECtHR 2 October 2012, no. 41242/08.

63 Sahin and Sahin v. Turkey, ECtHR (GC) 20 October 2011, appl. no. 13279/05.

64 See more elaborately below, section 6.4.2; for one example out of many, see Gablishvili v. Russia, ECtHR 26 June 2014, no. 39428/12.

65 E.g. Malone v. the United Kingdom, ECtHR 2 August 1984, no. 8691/79, para. 68; Goranova-Karanaeva v. Bulgaria, ECtHR 8 March 2011, no. 12739/05, para. 48; Gillan and Quinton v. the United Kingdom, ECtHR 12 January 2010, no. 4158/05, paras. 85-87; Weber and Saravia v. Germany, ECtHR 29 June 2006 (dec.), no. 54934/00, para. 95; Telegraaf Media Nederland Landelijke Media B.V. and Others v. the Netherlands, ECtHR 22 November 2013, no. 39315/06, para. 98. Indeed, administrative decisions disclosing arbitrariness always violate the Convention; see e.g. Fatullayev v. Azerbaijan, paras. 123124; Ternovszky v. Hungary, ECtHR 14 December 2010, no. 67545/09, para. 26; East/West Alliance Limited v. Ukraine, ECtHR 23 January 2014, no. 19336/04, para. 167.

66 E.g. M.S.S. v. Belgium and Greece, ECtHR (GC) 21 January 2011, no. 30696/09, para. 250. 
be based on informed consent. ${ }^{67}$ The informed consent requirement means, inter alia, that the individual must be given access to diagnostic facilities and, if so desired, a second opinion, and there must be a possibility for complaint and eventually judicial review. ${ }^{68}$ Similarly intricate administrative, regulative and judicial obligations have been formulated in relation to other issues, varying from abortion ${ }^{69}$ and assisted suicide ${ }^{70}$ to protection of journalistic sources ${ }^{71}$ and child abduction, ${ }^{72}$ and from decision-making in relation to hazardous industrial installations ${ }^{73}$ to prevention of human trafficking and exploitation, ${ }^{74}$ domestic violence $^{75}$ and child abuse. ${ }^{76}$

\subsubsection{Taking Convention Standards into Account}

This chapter does not aim to map out all different obligations following from the Convention that are related to national judicial and administrative procedures. It is clear from the above examples that this would be too great an exercise, since detailed sets of obligations have been developed in relation to a wide number of fundamental rights issues. It is important to note, however, that such obligations have considerable impact on national judicial and administrative decision-making. Perhaps most interesting for the purposes of the current chapter, and therefore warranting more detailed attention, is the Court's requirement that national courts (as well as national administrative bodies) take due account of the standards for review developed in the Court's case law. On the one hand, the Court has held that the Convention does not impose a certain constitutional structure on the States and it does not

67 E.g. Codarcea v. Romania, ECtHR 2 June 2009, no. 31675/04, paras. 102ff; Csoma v. Romania, ECtHR 15 January 2013, no. 8759/05, paras. 42ff.

${ }^{68}$ E.g. Tysiac v. Poland, ECtHR 20 March 2007, no. 5410/03; R.R. v. Poland, ECtHR 26 May 2011, no. 27617/04; Assunção Chaves v. Portugal, ECtHR 31 January 2012, no. $61226 / 08$.

${ }^{69}$ E.g. A., B. and C. v. Ireland, ECtHR (GC) 16 December 2010, no. 25579/05, paras. 249 and 267.

70 E.g. Gross v. Switzerland, ECtHR 14 May 2013, no. 67810/10.

${ }^{71}$ E.g. Sanoma v. the Netherlands, ECtHR (GC) 14 September 2010, no. 38224/03, paras. 88, 90-92.

72 E.g. X. v. Latvia, ECtHR (GC) 26 November 2013, no. 27853/09, para. 107.

73 E.g. Öneryildiz v. Turkey, ECtHR (GC) 30 November 2004, no. 48939/99, para. 90.

74 E.g. Rantsev v. Cyprus and Turkey, ECtHR 7 January 2010, no. 25965/04; C.N. v. the United Kingdom, ECtHR 13 November 2012, no. 4239/08.

75 E.g. Opuz v. Turkey, ECtHR 9 June 2009, no. 33401/02; Busuioc v. Moldava, ECtHR 16 July 2013, no. 61382/09.

${ }^{76}$ E.g. O'Keeffe v. Ireland, ECtHR (GC) 28 January 2014, no. 35810/09, para. 148. 
require that the states make the Convention directly enforceable through the national courts. ${ }^{77}$ The States remain free to decide how they want to meet their obligations under the Convention, although the Court generally requires the State to organise its internal structure in such a manner as to be able to meet its Convention obligations. ${ }^{78}$ In line with this, the Court never expressly held that national courts (or, for that matter, any other national organs, institutions or administrative bodies) should have certain competences or be able to adopt certain approaches. Nevertheless, the Court may condemn a State if a violation of the Convention results from a lack of competence to disapply or nullify legislation that is contrary to the Convention. ${ }^{79}$ In fact, thus, the national courts need to have avail of certain competences and procedural instruments in order to be able to comply with their obligations under the Convention. Furthermore, the States are not completely free in meeting their overall obligation to respect the Convention. In particular, it follows from cases such as Pla and Puncernau v. Andorra that the domestic courts are obliged to take the Convention into account in interpreting national law and even national contracts. ${ }^{80}$ It is clear from this ruling that the States can be held responsible for interpretations and judgments of the national courts, and that the national courts have to copy the Court's approach to comply with the minimum standards of the Convention. ${ }^{81}$ Moreover, in the case of Fabris v. France, the Court found that the domestic courts are obliged 'to ensure, in conformity with their

77 Swedish Engine Drivers' Union v. Sweden, ECtHR 6 February 1976, no. 5614/72, para. 50; James and Others v. UK, ECtHR 21 February 1986, no. 8793/79, para. 85.

78 Cf. E. Klein, 'Should the Binding Effect of the Judgments of the European Court of Human Rights Be Extended?', in P. Mahoney (ed), Protecting Human Rights: the European Perspective (Köln: Heymanns 2000) pp. 705-713, at p. 709; see also Assanidze v. Georgia, ECtHR 8 April 2004, no. 71503/01, para. 146.

${ }^{79}$ Cf. Losonci Rose and Rose v. Switzerland, ECtHR 9 November 2010, no. 664/06, para. 50.

80 Pla and Puncernau v. Andorra, ECtHR 13 July 2004, no. 69498/01. In similar vein, see Khurshid Mustafa and Tarzibachi v. Sweden, ECtHR 16 December 2008, no. 23883/06. See also, outside the sphere of contractual obligations, Paulić v. Croatia, ECtHR 22 October 2009, no, 3572/06, para. 42 ('no legal provision of domestic law should be interpreted and applied in a manner incompatible with Croatia's obligations under the Convention') and, rather more implicitly, X. v. Latvia, ECtHR (GC) 26 November 2013, no. $27853 / 09$, para. 107.

${ }^{81}$ See e.g. E. Bjorge, 'National Supreme Courts and the Development of ECHR Rights', 9 International Journal of Constitutional Law (2011) pp. 5-31, giving more examples of cases from which it appears that national courts must apply the principle of evolutive interpretation; see also L. Garlicki, 'Contrôle de constitutionnalité et contrôle de conventionalité. Sur le dialogue des juges', in La conscience des droits. Mélanges en l'honneur de Jean-Paul Costa (Paris, Dalloz 2011) pp. 271-280 at pp. 274-275. 
constitutional order and having regard to the principle of legal certainty, the full effect of the Convention standards, as interpreted by the Court'. ${ }^{82}$ Consequently, when domestic courts are confronted with legislative provisions that can be interpreted in different ways, they should use their competence to ensure that their interpretations are in conformity with the standards formulated by the ECtHR. One may even read the case as implying that national courts should set aside legislation that clearly conflicts with ECHR provisions as interpreted by the ECtHR. ${ }^{83}$

This line of case law evidences that relatively high demands are placed on the national authorities. The legislature must make sure that courts and administrative bodies can dispose of clear and well-prepared legislative standards that they can apply in an individualised manner to concrete cases. Moreover, administrative and judicial authorities have an important task of their own to make sure individual decisions and judgments are in conformity with the Convention standards as defined by the Court.

\subsection{Procedural Review of Legislation}

\subsubsection{Introduction}

As mentioned in section 6.1, many judgments of the Court focus on the quality and transparency of the national procedures and judicial remedies that have been used in relation to the disputed decision or rule. Arguably, there is a procedural aspect in those cases where the Court finds that domestic legislation offers insufficient guarantees against arbitrary application. ${ }^{84}$ In those cases, the Court will usually hold that the legislation does not comply with the requirement of 'legality', or that the interference is not 'prescribed by law', as required by the Convention. For example, if there are no sufficient procedural guarantees to protect against arbitrary application of discretionary powers, or if legislation does not provide for sufficient clarity and forseeability, the Court usually will find a violation of the Convention, without even looking into the substantive reasonableness of an interference. ${ }^{85}$ The current section will

82 Fabris v. France, ECtHR (GC) 7 February 2013, no. 16574/08, para. 75.

${ }^{83}$ See further on this reading the case-note by Gerards to the case in European Human Rights Cases 2013/88 (in Dutch).

${ }^{84}$ See the examples mentioned in section 6.2.2 above; for one example out of many, see Golovan v. Ukraine, ECtHR 5 July 2012, no. 41716/06.

${ }^{85}$ See the case law discussed above, section 6.2.3.1; for some representative examples of application in different situation types, see M.M. v. the United Kingdom, ECtHR 
not focus on such 'prescribed by law' judgments, however. It is rather more interested to see how procedural-type arguments are used in relation to the review of the reasonableness or proportionality of the legislative measures at stake. It is there, after all, that procedural arguments can supplement or even be an alternative to substantive reasonableness review.

The analysis of the case law reveals a difference between two types of procedural review of legislation in the context of proportionality issues, i.e., review in which positive inferences are made and cases in which such inferences are negative. ${ }^{86}$ This section further explains this distinction, as well as the differences apparent from the Court's case law as to the nature and effects of these inferences (section 6.3.2). Subsequently, a further typology is made of different categories of cases in which the Court is most likely to rely on procedural-type arguments in relation to review of legislation (section 6.3.3). Review of judgments by domestic courts or of individualised administrative decisions is discussed in section 6.4.

\subsection{2 'Positive' and 'Negative' Procedural Review of Legislation}

\subsubsection{Positive Procedural Review of Legislation}

In a few cases, the Court seems to have attached positive value to the fact that a decision or rule is prepared and adopted with the greatest care and after extensive deliberation, in an open and transparent decision-making process. In these cases, thus, the Court's approach seems to be closely connected with the positive obligations discussed in section 6.2.2. A very clear example of this is the somewhat older case Maurice v. France, ${ }^{87}$ which related to the very sensitive and complex issue of compensation in cases of wrongful birth. ${ }^{88}$ The applicants argued that the relevant legislation violated their rights under Article 8 of the Convention because it offered a generally lower level of compensation than they could have obtained under the former case law of the French courts. In its judgment in the case, the Court paid close attention to the quality of the process that

13 November 2012, no. 24029/07; Casuneanu v. Romania, ECtHR 16 April 2013, no. 22018/10; Petrova v. Latvia, ECtHR 24 June 2014, no. 4605/05. In some cases, the Court does review the application of the legislation, but again it may do so in a rather procedural manner; see e.g. Topcic-Rosenberg v. Croatia, ECtHR 14 November 2013, no. 19391/11.

${ }^{86}$ Cf. also Kavanagh 2014, supra n. 2, p. 473.

87 Maurice v. France, ECtHR (GC) 6 October 2005, no. 11810/03.

${ }^{88}$ See Gerards, supra n. 2, section 6.3.3. 
had led to the adoption of the legislation. It stressed that there had been a 'stormy nation-wide debate' on the issue, in which politicians, interest groups and individuals had participated, and that close attention had been paid to all relevant legal, ethical and social considerations. It concluded that 'there is no serious reason for the Court to declare contrary to Article $8 \ldots$ the way in which the French legislature dealt with the problem or the content of the specific measures taken to that end'. ${ }^{89}$ The Court thus did not address the substantive issues of reasonableness and proportionality of the interference, restricting its review to procedural matters. In later cases, too, the Court has expressly mentioned the quality and extensiveness of parliamentary debates underlying legislation that restricts the exercise of Convention rights and it has considered this an important reason for holding the outcome of the decision-making process to be compatible with the Convention. ${ }^{90}$

The procedural arguments discernible in the case law discussed above relate to the quality of the process and deliberations underlying a certain piece of legislation, but positive procedural review also may take a different form. For example, the Court may expressly take into consideration that legislation allows for further concretisation and individualisation, thus offering a possibility to administrative authorities and courts to apply full reasonableness and proportionality review. ${ }^{91}$ The same is true if national legislation generally provides for an intricate and well-considered set of remedies to prevent fundamental rights violations, which may help the domestic authorities to comply with positive obligations following from the Convention..$^{92}$ Such possibilities for procedural fairness and procedural due care may positively influence the outcome of the case.

It must be noted, however, that the Court does not always rely on this procedural approach to the same degree. This can be illustrated by the case of Lindheim v. Norway, which concerned Norwegian legislation on

89 Maurice v. France, ECtHR (GC) 6 October 2005, no. 11810/03, para. 124.

90 E.g. Animal Defenders International v. the United Kingdom, ECtHR (GC) 22 April 2013, no. 48876/08, paras. 113-116; Shindler v. the United Kingdom, ECtHR 7 May 2013, no. 19840/09; The National Union of Rail, Maritime and Transport Workers v. the United Kingdom, ECtHR 8 April 2014, no. 31045/10.

${ }^{91}$ E.g. Schilder v. the Netherlands, ECtHR 16 October 2012 (dec.), no. 2158/12; Lohuis and Others v. the Netherlands, ECtHR 30 April 2013 (dec.), no. 37265/10; Peruzzo and Martens v. Germany, ECtHR 4 June 2013 (dec.), nos. 7841/08 and 57900/12.

92 E.g. Wilson v. the United Kingdom, ECtHR 23 October 2012 (dec.), no. 10601/09; however, it is also clear that such legislation must be applied in a proper manner, see e.g. E.M. v. Romania, ECtHR 30 October 2012, no. 43994/05. 
ground lease contracts and which revolved around the balance the national legislature had struck between the social and financial burdens for lessors and lessees. ${ }^{93}$ The Court paid considerable attention to the legislative process and it accepted that the Norwegian Parliament had carefully considered all relevant interests and had balanced them in a way that seemed reasonable to it. In addition, it expressly 'appreciated' the way the Norwegian Supreme Court had applied the Convention standards in reviewing the legislation. ${ }^{94}$ Given the approach discussed above, this might lead one to expect the Court to embrace the outcome reached by the Norwegian Parliament and the Norwegian Supreme Court, even more so because the case concerned a difficult socioeconomic policy issue. The Court did not do so, however. Instead, it substituted the national 'fair balance' for one its own, finding that the national authorities had taken insufficient account of certain aspects that it itself considered of importance to the balance to be struck. ${ }^{95}$ This example may go to show that the Court's procedural review is not (yet) consistently applied.

\subsubsection{Negative Procedural Review of Legislation}

While in the case law discussed above, the Court draws positive inferences from the quality of the national legislative process, procedural arguments also may play a 'negative' role. A well-known example can be seen in the case of Hirst v. the United Kingdom, ${ }^{96}$ where the Court found it problematic that the British Parliament had never expressly and extensively deliberated on the choice to exclude all prisoners (regardless of the duration of their sentence or the nature of the crimes committed) from the right to vote. It seemed that, regardless of the substantive reasons for and against such a complete, blanket prohibition, the Court would not have accepted the legislation for the lack of procedural safeguards surrounding its adoption. ${ }^{97}$ Thus, the Court (at least partly) avoided a substantive assessment of the reasonableness of the exclusion

93 Lindheim and Others v. Norway, ECtHR 12 June 2006, nos. 13221/08 and 2139/10.

94 Lindheim, para. 135; see also Kavanagh, supra n. 2, p. 473.

95 For a similar example, see Biao v. Denmark, ECtHR 25 March 2014, no. 38590/10, paras. 79-103; interestingly, although the Court on substantive grounds clearly disagreed with the Danish legislature and the Danish Supreme Court in the case and expressly doubted the Convention compatibility of the limitations contained in the legislation, it did not find a violation of the Convention because it accepted that there was a sufficient justification in the concrete circumstances of the case.

96 Hirst (No. 2) v. the United Kingdom, ECtHR (GC) 6 October 2005, no. 74025/01.

97 Hirst, paras. 79-80. 
of prisoners by relying on procedural arguments. In other cases, too, the Court has given attention to a lack of sound parliamentary debate on interferences with fundamental rights, although in most cases, this is combined with more substantive reasons for finding a violation. ${ }^{98}$

Another variant of negative review of legislation tunes in with the obligation to provide for a possibility of individualised review, which was discussed in section 6.2.2. In the Hirst case, the Court clearly also regarded it as problematic that the legislation did not provide for further individualisation and for concrete review of proportionality by a court. In other cases, too, the Court has held it against the State that it only provided for general and indiscriminate legislation, since this would stand in the way of concrete and substantive proportionality review by the courts. ${ }^{99}$ Moreover, in several cases, such as cases concerning abortion and euthanasia, the Court has found a violation of the Convention because the State had not complied with its positive obligation to ensure sufficiently clear and foreseeable legislation. ${ }^{100}$

\subsubsection{Importance of 'Procedural-Type' Arguments for the Court's Reasoning}

It is clear, thus, that there are two main types of procedural review of legislation. The first is a 'negative' type of procedural review, in which the Court may find a violation due to the lack of sound preparation of legislation or due to procedural flaws. The second is a 'positive' type, in which the Court may commend the national authorities for the quality of the legislative process.

Interestingly, there appears to be a difference between the two types of review as to the degree to which the procedural aspect determines the outcome of the Court's reasonableness review. ${ }^{101}$ In the 'positive' examples mentioned above, the argument played an important role, but the Court also looked at more substantive aspects related to the

98 E.g. Anchugov and Gladkov v. Russia, ECtHR 4 July 2013, nos. 11157/04 and 15162/05, para. 108; Dubská and Krejzová v. the Czech Republic, ECtHR 11 December 2014, nos. $28859 / 11$ and 28473/12. For some other examples and a further analysis, see Popelier and Van de Heyning, supra n. 2, p. 254.

99 E.g. Godelli v. Italy, ECtHR 25 September 2012, no. 33783/09; Ricci v. Italy, ECtHR 8 October 2013, no. 30210/06.

100 E.g. A., B. and C. v. Ireland, ECtHR (GC) 16 December 2010, no. 25579/05; Gross v. Switzerland, ECtHR 14 May 2013, no. 67810/10.

101 See also Kavanagh, supra n. 2, p. 473, although she mainly notes that there is a difference in frequency of the use of both types of argument (positive-type review occurring more often than negative-type review). 
proportionality of the interference, and the existence or lack of a certain European consensus on its acceptability, even if it did do so rather superficially. In fact, in none of the 'positive' procedural review cases analysed for the purposes of this chapter, the Court paid solely attention to the quality of the legislative debate. Even in cases in which the Court really seemed to find that the legislature had fully considered all relevant arguments and there was no reason to deviate from its findings, it appears that the existence of a lack of consensus or substantive reasonableness arguments played an important role in supporting the Court's findings. ${ }^{102}$ In some cases, the Court even did not at all seem to give real weight to the existence of an elaborate national debate. The case of S.A.S. v. France, for example, concerned the delicate issue of a prohibition of wearing a full face veil in public places. ${ }^{103}$ The relevant legislation had been the product of a lengthy and intensive national debate in France, which was conducted both inside and outside parliament, and which was carefully mapped out by the Court. Rather than attaching any positive value to the existence of such debate as such, however, as might be expected based on the reasoning in cases such as Maurice, ${ }^{104}$ the Court in this judgment evaluated all different arguments advanced in the debate on their merits and for their persuasiveness. Although on some points, it agreed with the government and the national legislature, such agreement was based on substantive grounds, rather than on a presumption of fairness of the outcomes of a sound legislative procedure. Hence, although the existence of procedurally sound legislative procedures can constitute an important argument supporting the conclusions the Court wants to arrive at, it is clear that it is hardly ever decisive for the Court's findings. ${ }^{105}$

By contrast, procedural-type arguments appear to be more important in 'negative' cases of review. This is particularly so in the most common cases of procedural defects, i.e. cases where legislation did not provide for sufficient procedural guarantees as such (e.g. due to a lack of clarity or a lack of guarantees against arbitrariness), or where legislation did not allow for individualisation. In many such cases, the finding of a lack of procedural due care may immediately result in a finding of a violation of the Convention. By contrast, however, if the procedural shortcoming

102 Shindler v. the United Kingdom, ECtHR 7 May 2013, no. 19840/09, para. 115; Animal Defenders International v. the United Kingdom, ECtHR (GC) 22 April 2013, no. 48876/ 08, paras. $118-124$.

103 S.A.S. v. France, ECtHR (GC) 1 July 2014, no. 43835/11. ${ }^{104}$ See supra n. 87.

105 Cf. also Kavanagh, supra n. 2, p. 475; Popelier 2012, supra n. 2, p. 266. 
mainly is a lack of procedural due care in the preparation or drafting of legislation, as in the Hirst case, it seems that it is merely one reason or argument for the Court to be taken into account in its overall substantive assessment of the reasonableness of the resulting legislation, rather than an argument that is decisive of its own. Such procedural review then, again, is flanked by a number of arguments of a more substantive nature. In the prisoners' voting rights cases, for example, the Court also stressed the overall importance of the right to vote within a democratic society and it mentioned the legitimacy of the aims pursued by the limitation of the right to vote for prisoners. ${ }^{106}$

\subsubsection{Types of Cases in Which Procedural Review is Applied}

Regardless of whether negative or positive inferences are drawn from the Court's procedural review, it appears that the Court is most inclined to attach value to the quality of the legislative process in hard cases with a high degree of sensitivity. Closer analysis of the cases discussed in section 6.3.2 discloses that procedural review is mainly applied in two types of sensitive cases, i.e. cases relating to complex choices in socioeconomic policy fields, and 'dilemma-cases'. In addition, procedural review appears to be closely connected to the width of the margin of appreciation that is granted to the states. ${ }^{107}$

In cases concerning socio-economic rights, the Court generally provides the States with a wide margin of appreciation, in particular because national authorities are better placed than the Court itself is to make assessments of facts and make well-balanced choices. ${ }^{108}$ In these cases, the Court often limits its substantive assessment of the

106 E.g. Hirst (No. 2) v. the United Kingdom, ECtHR (GC) 6 October 2005, no. 74025/01 and Anchugov and Gladkov v. Russia, ECtHR 4 July 2013, nos. 11157/04 and 15162/05.

107 On the interrelationship between the margin of appreciation doctrine and procedural review, see also O.M. Arnardóttir, 'Organised Retreat? The Move from "Substantive" to "Procedural" Review in the ECtHR's Case Law on the Margin of Appreciation', European Society of International Law 2015 Annual Conference, www.ssrn.com/abstract=2709669.

108 See in more detail e.g. J.H. Gerards, 'The ECtHR's Response to Fundamental Rights Issues Related to Financial and Economic Difficulties - The Problem of Compartmentalisation', 33 Netherlands Quarterly of Human Rights 2015 (3) pp. 274-292; A.E.M. Leijten, 'Defining the Scope of Economic and Social Guarantees in the Case Law of the ECtHR' in E. Brems and J. Gerards (eds) Shaping Rights in the ECHR. The Role of the European Court of Human Rights in Determining the Scope of Human Rights (Cambridge, CUP 2014) pp. 109-136; E. Palmer, 'Protecting Socio-Economic Rights through the European Convention of Human Rights: Trends and Development in the European Court of Human Rights' (2009) 2 Erasmus Law Review, p. 408. 
reasonableness of the resulting interferences to a test of manifest unreasonableness or a test of 'individual and excessive burden'. ${ }^{109}$ At the same time, it is important for the Court to uphold Convention standards and exercise its supervisory task. It is not surprising, therefore, that the Court has chosen to support its very deferential reasonableness review by elements of procedural review. ${ }^{110}$ After all, if the legislation itself is not to be looked at too closely, it is all the more important to ensure that such legislation is adopted through a fair decision-making process. ${ }^{111}$ Indeed, the very 'better-placed argument' is based on the presupposition the national authorities pay due attention to all relevant interests and conduct a sound balancing exercise. ${ }^{112}$ It is then of importance for the Court to check whether the national legislative and administrative bodies actually have done so and whether they have complied with the relevant standards in the field.

The second category of 'sensitive' cases is that involving ethical or moral dilemmas. The Court is frequently confronted with such cases, which may of course relate to abortion or euthanasia, ${ }^{113}$ to choices closely related to personal autonomy (such as the choice to become a genetic parent), ${ }^{114}$ or to the rights of same-sex partners, ${ }^{115}$ but also to more societal dilemmas, such as how to deal with religious expressions in the public sphere, ${ }^{116}$ or to what extent to respect and guarantee fundamental rights of prisoners, such as the right to vote ${ }^{117}$. Just as for cases in the socio-economic sphere, it is not surprising that positive arguments of a procedural nature surface in particular in this category of 'dilemma-cases'. Unavoidably, they are hard cases, in which conflicting rights and interests play a role and in which it is very difficult to arrive at one rational or legal conclusion. ${ }^{118}$ Cases involving moral dilemmas inherently ask for value judgments to be made, and the

109 Ibid

110 See e.g. Hatton and Others v. the United Kingdom, ECtHR (GC) 8 July 2003, no. 36022/97 and cf. Popelier and Van de Heyning, supra n. 2, p. 252.

111 Cf. also Kavanagh, supra n. 2; Popelier 2012, supra n. 2.

112 See further Gerards, supra n. 2 and Popelier and Van de Heyning, supra n. 2, p. 251.

113 E.g. A., B. and C. v. Ireland, ECtHR (GC) 16 December 2010, no. 25579/05; Gross v. Switzerland, ECtHR 14 May 2013, no. 67810/10.

114 E.g. Dickson v. the United Kingdom, ECtHR (GC) 4 December 2007, no. 44362/04.

115 E.g. X. and Others v. Austria, ECtHR (GC) 19 February 2013, no. 19010/07.

116 E.g. S.A.S. v. France, ECtHR (GC) 1 July 2014, no. 43835/11.

117 See the various cases discussed above, in particular Hirst (No. 2) v. the United Kingdom, ECtHR (GC) 6 October 2005, no. 74025/01.

${ }^{118}$ Next to the cases expressly discussed here, see e.g. Evans v. the United Kingdom, ECtHR (GC) 10 April 2007, no. 6339/05, para. 89 and Söderman v. Sweden, ECtHR (GC) 12 November 2013, no. 5786/08. 
Court usually does not regard it as its task to replace national value judgments for its own. For that reason, it tends to leave a very wide margin of appreciation to the States in these cases. Again, however, probably because of the importance of what is at stake in these cases, the Court may pay special attention to the care taken at the national level to arrive at certain choices. ${ }^{119}$ Especially in dilemma-cases, it is apparent that the Court places great value on the existence of societal and legislative debates, which preferably involve a large number of stakeholders and are very open in nature, and only after due deliberation in Parliament lead to the adoption of legislation. As was demonstrated above, the existence of such a wide and deep national debate makes it easier for the Court to accept the reasonableness of the outcomes of that decision-making process.

Indeed, in cases of this type, the Court has rendered hardly any judgments in which it deviated from the outcomes of the national legislative process in dilemma-cases if it considers that underlying deliberations and debates have been sufficiently inclusive and comprehensive. Although even in these cases, the Court always provides for a substantive check of the reasonableness of the legislation of its own, this check usually is a very deferential one and it is still of a relatively procedural nature, to the extent that the Court mainly checks whether the national authorities have identified all relevant interests and whether the balance they have struck is not manifestly unreasonable.

Nevertheless, there are some clear dilemma-cases in which the Court does not at all apply a procedural approach. An example is the case of $X$. and Others v. Austria, which concerned a difference in treatment between unmarried different-sex couples and same-sex couples in respect of adoption. ${ }^{120}$ Although this obviously was a hard case in which sensitive issues were at stake, the Court chose to apply a rather strict and clearly substantive proportionality review, carefully examining the various arguments adduced by the government for their reasonableness and persuasiveness. The quality of the national decision-making procedure did not play a role at all and the Court found, in clear deviation from the national legislature's view, that the difference in treatment could not be condoned. It is difficult to explain this deviation from the Court's usual approach, and the Court's judgment mainly seems to reveal that its procedural review case law is not (yet) fully consistent.

119 Cf. also Kavanagh, supra n. 2; Popelier 2012, supra n. 2; Popelier and Van de Heyning, supra n. 2, p. 253.

120 X. and Others v. Austria, ECtHR (GC) 19 February 2013, no. 19010/07. 


\subsubsection{Conclusion}

In sum, in relation to the assessment of reasonableness of legislation, the Court often relies on arguments of procedural quality in cases presenting a dilemma or in cases involving difficult socio-economic choices. In both types of cases, this can be understood from the Court's subsidiary position and its view that national authorities are usually better placed to make political and value choices, as well as from the Court's desire to make sure that these choices have been made in a sound and equitable manner. The argument from procedure may be used in these cases in both a negative and a positive manner, to the extent that a lack of procedural quality may contribute to the finding of a violation, while a sound and careful preparation of legislation may contribute to the acceptance of the interference as reasonable and justifiable. In both types of cases, the Court mainly seems to regard the procedural arguments as supportive, i.e. as part of the overall set of arguments to be taken into account in building a 'narrative' leading up to a certain decision, although, especially in some 'negative' cases, the impact may be stronger. ${ }^{121}$ Indeed, this seems to be in line with the Court's overall argumentative approach. ${ }^{122}$ The Court is not likely to hold on to a strict canon of argumentation that requires it to first look at procedural arguments and, if it can build its conclusion on those arguments alone, stop there. Rather the Court tends to rely on a discursive approach, mentioning a wide number of different arguments in its judgments, including procedural arguments, none of which are apparently more important or decisive than another. ${ }^{123}$ It is only the set of arguments taken together and read in their interrelationship that can support the final outcome.

\subsection{Procedural Review of National Judicial Decision-Making}

\subsubsection{Introduction}

The second main type of cases in which the Court relies on arguments of procedural fairness and procedural quality is that in which it reviews

${ }^{121}$ For the typical narrative structure of the Court's judgments, see further J.H. Gerards, 'European Court of Human Rights', in: A. Jákab, A. Dyevre and G. Itzcovich (eds), Comparative Constitutional Reasoning (Cambridge, Cambridge University Press, forthcoming). See also S. Smet, Resolving Conflicts between Human Rights: A Legal Theoretical Analysis in the Context of the ECHR (Dissertation Ghent University 2014), speaking of a 'net' of arguments.

122

Ibid. $\quad{ }^{123}$ Ibid. 
judicial decision-making. ${ }^{124}$ In relation to this second type of cases, the interconnectedness between (procedural) positive obligations and procedural review is particularly strong. The Court greatly values its partnership and dialogue with the national courts, which it regards as important to ensure the protection of the Convention on the domestic level. ${ }^{125}$ It is for that reason that the Court requires that the national courts take due account of the Convention standards and criteria in their case law. ${ }^{126}$

The implicit notion of 'partnership' in these cases also has found a translation into the Court's procedural review. Just as in cases concerning national legislation, the Court may pay attention to the quality of the national judicial proceedings and it may find support in its findings for reaching a certain outcome. Again, these findings may lead to either positive or negative inferences, as is further discussed in sections 6.4.2 and 6.4.3. In addition, there is a third category to be distinguished, which includes judgments in which the Court does not pay express attention to procedural requirements or compliance with Convention standards. This category is described in section 6.4.4.

\subsection{2 'Positive' Procedural Review of National Judicial Decisions}

In a large number of cases, the Court has paid 'positive' attention to national judicial decision-making by accepting that if the national courts have expressly taken account of the Court's case law and they have dutifully applied the substantive standards developed by the Court, there is not much need or room for the Court to deviate from their conclusions. Indeed, the Court has held that 'where the balancing exercise has been undertaken by the national authorities in conformity with the criteria laid down in the Court's case law, the Court would require strong reasons to substitute its view for that of the domestic courts'. ${ }^{127}$

124 There are also cases concerning the procedural quality of administrative decision-making, but because they are rather similar to cases concerning judicial decision-making they are not discussed here separately; for some representative examples demonstrating the similarity of the Court's approach in administrative decision-making cases, see e.g. C.N. v. the United Kingdom, ECtHR 13 November 2012, no. 4239/08; Maksymenko and Gerasymenko v. Ukraine, ECtHR 16 May 2013, no. 49317/07; Lavida and Others v. Greece, ECtHR 30 May 2013, no. 7973/10; Winterstein and Others v. France, ECtHR 17 October 2013, no. 27013/07; East/West Alliance Limited v. Ukraine, ECtHR 23 January 2014, no. 19336/04.

See section 6.2.3. ${ }^{126}$ See in more detail Gerards, supra n. 2.

127 Von Hannover (No. 2) v. Germany, ECtHR 7 February 2012, nos. 40660/08 and 60641/ 08, para. 107. See earlier also MGN Limited v. the United Kingdom, ECtHR 12 June 2012, 
Clearly the Court can rely on this approach in relation to issues for which it has developed a strong and substantive body of case law identifying a set of standards and criteria that can be readily applied by national courts. For example, in relation to cases concerning the intended expulsion of immigrants, the Court has distinguished a variety of situation types in its case law, for each of which it has provided for an extensive 'catalogue' of relevant factors and criteria. ${ }^{128}$ Similarly, for cases on the freedom of expression, such as cases on the publication of photographs of the private lives of famous people or cases on defamation by the press, the Court has created a list of 'general principles' to be taken into account in deciding on the reasonableness of limitations. ${ }^{129}$ Although the Court seems to have devised such criteria and standards mainly for its own decision-making, they can just as well be used by national courts, and the Court often expresses its approval if they have done so. In many cases, the Court mainly looks into whether the national courts have actually relied on these factors and criteria and have duly taken them into account in their decision-making. ${ }^{130}$ If so, it will not likely find a violation of the Convention. Such positive procedural reasoning in particular can be seen in private- and family law-related cases, such as cases concerning custody, guardianship, adoption or establishment of paternity, ${ }^{131}$ some cases

no. 39401/04, paras. 150 and 155 and more recently e.g. Aksu v. Turkey, ECtHR (GC) 15 March 2012, nos. 4149/04 and 41029/04, para. 67; Blaja News Sp. Z O.O. v. Poland, ECtHR 26 November 2013, no. 59545/10. For a slightly different, though still similar approach, see Eternit v. France, ECtHR 27 March 2012 (dec.), no. 20041/10.

128 See in particular e.g. Uner v. the Netherlands, ECtHR (GC) 18 October 2006, no. 46410/ 99 and Maslov v. Austria, ECtHR (GC) 23 June 2006, no. 1638/03.

129 For a summary of these requirements, see e.g. Von Hannover (No. 2) v. Germany, ECtHR 7 February 2012, nos. 40660/08 and 60641/08. For some applications, see e.g. Mouvement raëlien Suisse v. Switzerland, ECtHR (GC) 13 July 2012, no. 16354/06; Peta Deutschland v. Germany, ECtHR 8 November 2012, no. 43481/09; Remuszenko v. Poland, ECtHR 16 July 2013, no. 1562/10; Ojala and Etukeno Oy v. Finland, ECtHR 14 January 2014, no. 69939/10; Lillo-Stenberg and Sather v. Norway, ECtHR 16 January 2014, no. 13258/09; Matúz v. Hungary, ECtHR 21 October 2014, no. 73571/10; Von Hannover (No. 3) v. Germany, ECtHR 19 September 2013, appl. no. 8772/10. See similarly some cases relating to political parties; e.g. Eusko Abertzale Ekintza-Accion Nacionalista Vasca (EAE-ANV) v. Spain (No. 2), ECtHR 15 January 2013, no. 40959/09.

130 See the cases mentioned supra, n. 127.

131 E.g. Krisztián Barnabás Tóth v. Hungary, ECtHR 12 February 2013, no. 48494/06; Dmitriy Ryabov v. Russia, ECtHR 1 August 2013, no. 33774/08; A.L. v. Poland, ECtHR 18 February 2014, no. 28609/08; Z.J. v. Lithuania, ECtHR 29 April 2014, no. 60092/12; Buchs v. Switzerland, ECtHR 27 May 2014, no. 9929/12; I.S. v. Germany, ECtHR 5 June 2014, no. 31021/08. For an interesting case in which the Court expressly embraced the criteria adopted by the national court, rather than reviewing whether the national 
concerning domestic violence ${ }^{132}$ and cases concerning moral dilemmas ${ }^{133}$ or human dignity and personal autonomy. ${ }^{134,135}$ In these cases, the Court often concludes that there is no violation of the Convention if it finds it established that the national procedures have been fair and the national courts have applied the Court's case law standards, as well as respected their procedural positive obligations. A similar approach is applied in relation to cases about the state's obligations to protect individuals against hazardous situations, such as natural disasters, life-threatening disease or serious environmental pollution. In this area, too, the Court has developed an elaborate case law, setting clear positive obligations to be met by decision-making authorities, such as obligations to provide for clear legislation and create special and transparent decision-making procedures, to provide for sufficient information, to safeguard involvement of interested parties, to provide for effective judicial remedies and so on. ${ }^{136}$ In many of these cases, the Court mainly assesses whether these positive obligations have been complied with. If so, there is hardly any need for it to question the reasonableness of the decision reached, and it may instead only scrutinise the case to see if it discloses any 'manifest error of appreciation'. ${ }^{137}$

For the purposes of this chapter, it is important to emphasise that the Court appears to apply procedural-type review mainly in cases in which it has provided for elaborate lists of factors and standards to be taken into account. ${ }^{138}$ Another commonality of the cases mentioned above is that they are strongly fact-based and they require a valuation of conflicting interests or of socio-economic factors. In that respect, they are similar to the types of cases about legislation in which the Court relies on

court applied the Convention standards, see Harroudj v. France, ECtHR 4 October 2012, no. $43631 / 09$.

132 E.g. Wilson v. the United Kingdom, ECtHR 23 October 2012 (dec.), no. 10601/09.

133 See in particular Stübing v. Germany, ECtHR 12 April 2012, no. 43547/08.

134 E.g. McDonald v. the United Kingdom, ECtHR 20 May 2014, no. 4241/12.

135 See also De la Flor Cabrera v. Spain, ECtHR 27 May 2014, no. 10764/09.

136 See already e.g. Öneryildiz v. Turkey, ECtHR (GC) 30 November 2004, no. 48939/99, para. 90; more recently, see e.g. Martínez Martínez and Pino Manzano v. Spain, ECtHR 3 July 2012, no. 61654/08; Vilnes and Others v. Norway, ECtHR 5 December 2013, nos. 52806/09 and 22703/10, para. 235; Brincat and Others v. Malta, ECtHR 24 July 2014, nos. $60908 / 11$ et al.

137 E.g. Hardy and Maile v. the United Kingdom, ECtHR 14 February 2012, no. 31965/07.

138 A rare exception is Julin v. Estonia, ECtHR 29 May 2012, nos. 16563/08 et al, in which the Court applied positive procedural review to a case concerning the level of court fees under Article 6 ECHR. This is not normally a situation type in which a catalogue of factors is applied, so it is not entirely clear why the Court chose to rely on this approach. 
procedural arguments and that were discussed in section 6.3.3. Here, too, the cases in which procedural review is applied appear to be either 'dilemma-cases', in which conflicting interests of rather similar weight are at stake or which relate to moral issues, ${ }^{139}$ or cases in which the national authorities are particularly well-placed to make decisions because socio-economic interests or national resources or capacity play a role or, more generally, because 'the national authorities have the benefit of direct contact with all the persons concerned. ${ }^{140}$

Interestingly, however, in hardly any of the cases in which this 'positive' type of procedural review is used, the Court takes its procedural approach to the fullest logical consequence, which would be that it would not at all look into the substance of the decision complained about. Surely, in some cases, the Court restricts itself to seeing whether the national court has taken sufficient heed of the various standards and positive obligations developed in the Court's case law and whether it has carefully applied the relevant criteria to the case at hand. ${ }^{141}$ Those cases come closest to a purely procedural-type review. ${ }^{142}$ In many other cases, however, while the Court expressly mentions that it will rely on a procedural approach or it accepts that the national authorities have carefully assessed the case, it still includes a number of more substantive arguments, complementing or comparing the national evaluation with one of its own. ${ }^{143}$ In none of these cases is it very clear why the Court

139 E.g. Mouvement raëlien Suisse v. Switzerland, ECtHR (GC) 13 July 2012, no. 16354/06; Koch v. Germany, ECtHR 19 July 2012, no. 497/09; Peta Deutschland v. Germany, ECtHR 8 November 2012, no. 43481/09.

140 E.g. Ahrens v. Germany, ECtHR 22 March 2012, no. 45071/09, para. 64.

141 See e.g. Von Hannover (No. 2) v. Germany, ECtHR 7 February 2012, nos. 40660/08 and 60641/08; Aksu v. Turkey, ECtHR 15 March 2012, nos. 4149/04 and 41029/04; Mouvement raëlien Suisse v. Switzerland, ECtHR (GC) 13 July 2012, no. 16354/06, paras. 67-75; Spyra and Kranczkowski v. Poland, ECtHR 25 September 2012, no. 19764/07; Peta Deutschland v. Germany, ECtHR 8 November 2012, no. 43481/09; Remuszenko v. Poland, ECtHR 16 July 2013, no. 1562/10; Von Hannover (No. 3) v. Germany, ECtHR 19 September 2013, no. 8772/10; A.L. v. Poland, ECtHR 18 February 2014, no. 28609/08.

142 E.g. Spyra and Kranczkowski v. Poland, ECtHR 25 September 2012, no. 19764/07; Krisztián Barnabás Tóth v. Hungary, ECtHR 12 February 2013, no. 48494/06.

143 E.g. Axel Springer AG v. Germany, ECtHR (GC) 7 February 2012, no. 39954/08 (the five dissenting judges in this case indeed disagreed with the majority judgment for this reason); Samsonnikov v. Estonia, ECtHR 3 July 2012, no. 52178/10; Küchl v. Austria, ECtHR 4 December 2012, no. 51151/06; Cichopek and Others v. Poland, ECtHR 14 May 2013 (dec.), no. 15189/10; Ojala and Etukeno Oy v. Finland, ECtHR 14 January 2014, no. 69939/ 10; Lillo-Stenberg and Sather v. Norway, ECtHR 16 January 2014, no. 13258/09; Ciesielczyk v. Poland, ECtHR 26 June 2012, no. 12484/05; Brincat and Others v. Malta, ECtHR 24 July 2014, appl. nos. 60908/11 et al. 
makes one or the other choice for a particular argumentative approach, especially since the Court does not provide any reasons for this. It can be concluded, therefore, just as in regard to national legislative decisionmaking, that procedural review may play a certain role, but the Court does not regard it as a full alternative to substantive review.

\subsection{3 'Negative' Procedural Review of National Judicial Decisions}

In addition to the positive form of procedural review of judicial decisionmaking, there is a 'negative' type of review. In negative-type procedural review cases, the Court is dismissive of a national judicial decision because the national court has paid insufficient heed to the fundamental rights aspects of a case or to the standards developed by the Court, the national judgment was inadequately reasoned or unduly formalistic, the national judicial proceedings were unfair, there has been no real review of the individual case and so on. ${ }^{144}$ Similarly, in cases where the Court has set elaborate procedural positive obligations, such as in relation to hazardous situations or infringements of physical or mental integrity, the Court may find a violation of the Convention if these obligations have not been complied with, even without really looking into the substantive arguments presented by the government. ${ }^{145}$ The same is true in many private- and family law-related cases, such as those relating to establishment of paternity, adoption or care orders, ${ }^{146}$ cases concerning child

144 E.g. Hirsi Jamaa and Others v. Italy, ECtHR 23 February 2012, no. 27765/09; Waldemar Nowakowski v. Poland, ECtHR 24 July 2012, no. 55167/11; Jucha and Żak v. Poland, ECtHR 23 October 2012, no. 19127/06; E.M. v. Romania, ECtHR 30 October 2012, no. 43994/05; OOO Ivpress and Others v. Russia, EHRM 22 January 2013, nos. 33501/04 et al.; Bugan v. Romania, ECtHR 12 February 2013, no. 13824/06; Rousk v. Sweden, ECtHR 25 July 2013, no. 27183/04; R.M.S. v. Spain, ECtHR 18 June 2013, no. 28775/12; Cumhuriyet Vakfi and Others v. Turkey, ECtHR 8 October 2013, no. 28255/07; Ringier Axel Springer Slovakia A.S. v. Slovakia (No. 2), ECtHR 7 January 2014, no. 21666/09; İhsan Ay v. Turkey, ECtHR 21 January 2014, no. 34288/04; Mugenzi v. France, ECtHR 10 July 2014, no. 52701/09; Matúz v. Hungary, ECtHR 21 October 2014, no. 73571/10.

145 E.g. Kolyadenko and Others v. Russia, ECtHR 28 February 2012, nos. 17423/05 et al; P. and S. v. Poland, ECtHR 30 October 2012, no. 57375/08; Vilnes and Others v. Norway, ECtHR 5 December 2013, nos. 52806/09 and 22703/10; Oruk v. Turkey, ECtHR 4 February 2014, no. $33647 / 04$.

146 E.g. K.A.B. v. Spain, ECtHR 10 April 2012, no. 59819/08; Santos Nunes v. Portugal, ECtHR 22 May 2012, no. 61173/08; M.D. and Others v. Malta, ECtHR 17 July 2012, no. 64791/10; A.K. and L. v. Croatia, ECtHR 8 January 2013, no. 37956/11; Ageyevy v. Russia, ECtHR 18 April 2013, no. 7075/10; R.M.S. v. Spain, ECtHR 18 June 2013, no. 28775/12; Antonyuk v. Russia, ECtHR 1 August 2013, no. 47721/10; Zhou v. Italy, ECtHR 21 January 2014, no. 33773/11. 
abduction $^{147}$ or cases about personal autonomy and informed consent. ${ }^{148}$ In these cases, the Court may conclude that national courts have taken insufficient care to comply with the procedural requirements formulated in the Court's case law. Similarly, in conformity with the requirement of individual decision-making rather than indiscriminate application of legislation, the Court has held it against the national courts if they have omitted to apply proportionality review in the concrete case at hand. ${ }^{149}$

The lack of procedural care in these cases often constitutes an important or even decisive reason for the Court to find a violation of the Convention. This forms an interesting contrast with the cases in which procedural carefulness and quality play a positive role, and where such procedural care usually is merely one argument considered next to a set of more substantive considerations. Nonetheless, even in the 'negative' cases, the Court sometimes pays attention to the substance of the case and the way in which the balance ought to have been struck, if only because some substantive review is necessary to establish if the authorities have taken insufficient care in deciding upon a certain matter. ${ }^{150}$ Perhaps it does do so to enable the national courts to improve their reasoning in subsequent, similar cases, or perhaps it does do so because it seems too 'empty' to base a judgment on procedural reasons alone. Regardless of the explanation, however, these cases clearly illustrate that the presence of procedural-type arguments is seldom decisive.

\subsubsection{No Procedural Review}

Although procedural arguments play at least some role in many of the recent cases decided by the Court, it is equally clear that the Court does not always rely on these arguments. Although there are some cases on expulsion or reputation in which the Court expressly mentions its reliance on procedural review, there still are far more cases in which

147 E.g. X. v. Latvia, ECtHR (GC) 26 November 2013, no. 27853/09.

148 E.g. A.K. v. Latvia, ECtHR 24 June 2014, no. 33011/08.

149 E.g. Bjedov v. Croatia, ECtHR 29 May 2012, no. 42150/09; Godelli v. Italy, ECtHR 25 September 2012, no. 33783/09; Henry Kismoun v. France, ECtHR 5 December 2013, no. 32265/10; Paulet v. the United Kingdom, ECtHR 13 May 2014, no. 6219/08; Gablishvili v. Russia, ECtHR 26 June 2014, no. 39428/12.

150 E.g. Waldemar Nowakowski v. Poland, ECtHR 24 July 2012, no. 55167/11; Czaja v. Poland, ECtHR 2 October 2012, no. 5744/05; Plesó v. Hungary, ECtHR 2 October 2012, no. 41242/08; Brezec v. Kroatia, ECtHR 18 July 2013, no. 7177/10; Jelševar and Others v. Slovenia, ECtHR 11 March 2014 (dec.), no. 47318/07. 
the Court embarks on its own review of reasonableness, re-balances all interests involved and arrives at a substantive conclusion without (elaborately) referring to the national decision-making process.

Logically, such a substantive, or at least hybrid, approach is visible in cases involving a legal or factual element which has not yet surfaced in the Court's case law or which concerns a rather special factual situation. ${ }^{151}$ These elements may require new standard-setting, a re-shuffling of existing standards of review, or at the least an adaptation of the standards to the special facts of the case. It is rather obvious that the Court in these cases refrains from relying on the national decision-making process, but chooses to (re-)define and apply its set of general principles. In the same vein, the Court will not rely on procedural arguments in cases where its own standards are in need of further clarification. ${ }^{152}$

Perhaps more surprising is that there are also cases in which the Court does not rely on procedural arguments, whereas the case itself, to all outside appearance, does not disclose any new elements. Many cases on freedom of expression, migration and deprivation of property, as well as some family law cases, are fully reviewed on substantive grounds, without the Court making (much) reference to procedural requirements, to the quality of the national judicial procedure or to the national court's review. ${ }^{153}$ Even in cases in which it would be relatively easy to apply

151 E.g. Popov v. France, ECtHR 19 January 2012, nos. 39472/07 and 39474/07; Vejdeland and Others v. Sweden, ECtHR 9 February 2012, no. 1813/07; Antwi and Others v. Norway, ECtHR 14 February 2012, no. 26940/10; Babar Ahmad and Others v. the United Kingdom, ECtHR 10 April 2012, nos. 24027/07 et al; S.F. and Others v. Sweden, ECtHR 15 May 2012, no. 52077/10; Tatar and Faber v. Hungary, ECtHR 12 June 2012, nos. 26005/08 and 26160/ 08; Schweizerische Radio- und Fernsehgesellschaft SRG v. Switzerland, ECtHR 21 June 2012, no. 34124/06; Fáber v. Hungary, ECtHR 24 July 2012, no. 40721/08; Alkaya v. Turkey, ECtHR 9 October 2012, no. 42811/06; Szima v. Hungary, ECtHR 9 October 2012, no. 29723/11; Bucur and Toma v. Romania, ECtHR 8 January 2013, no. 40238/02; Neij and Sunde Kolmisoppi v. Sweden, ECtHR 19 February 2013 (dec.), no. 40397/12; Eon v. France, ECtHR 14 March 2013, no. 26118/10; K.A.B. v. Sweden, ECtHR 5 September 2013, no. 886/11; I.B. v. Greece, ECtHR 3 October 2013, no. 552/10; Tierbefreier e.V. v. Germany, ECtHR 16 January 2014, no. 45192/09; Perikäinen v. Finland, ECtHR 4 February 2014, no. 11882/10; Mustafa Erdogan and Others v. Turkey, ECtHR 27 May 2014, nos. 346/04 and 39779/04; Erdoğan Gökçe v. Turkey, ECtHR 14 October 2014, no. 31736/04; Murat Vural v. Turkey, ECtHR 21 October 2014, no. 9540/07; Gough v. the United Kingdom, ECtHR 28 October 2014, no. 49327/11.

This may explain the reliance on substantive argumentative methods in cases such as $B$. v. the United Kingdom, ECtHR 14 February 2012, no. 36571/06 and Jeunesse v. the Netherlands, ECtHR (GC) 3 October 2014, no. 12738/10.

${ }^{153}$ For migration and expulsion cases, see e.g. Balogun v. the United Kingdom, ECtHR 10 April 2012, no. 60286/09; Nacic and Others v. Sweden, ECtHR 15 May 2012, no. 16567/10; A.A. and Others v. Sweden, ECtHR 28 June2012, no. 14499/09; Kissiwa 
the negative or positive procedural review forms discussed above, the Court usually applies a rather full reasonableness review. ${ }^{154}$ Equally remarkable is that procedural review is hardly ever visible in cases concerning, for example, the freedom of assembly and demonstration and the freedom of religion.

Even a close analysis does not disclose any good explanation for the Court's non-reliance on procedural arguments in these cases. Perhaps such an explanation must be looked for in the Court's overall argumentative approach, which is not very dogmatic, but rather discursive. ${ }^{155}$ In each case, the Court appears to provide for a number of arguments which, taken together, offer sufficiently persuasive reasoning to support its findings. Put differently, even if the Court's reliance on procedural arguments seems to disclose a degree of inconsistency, the Court itself

Koffi v. Switzerland, ECtHR 15 November 2012, no. 38005/07; Shala v. Switzerland, ECtHR 15 November 2012, no. 52873/09; Hamidovic v. Italy, ECtHR 4 December 2012, no. 31956/05; Butt v. Norway, ECtHR 4 December 2012, no. 47017/09; Udeh v. Switzerland, ECtHR 16 April 2013, no. 12020/09, Hasanbasic v. Switzerland, ECtHR 11 June 2013, no. 52166/09; Vasquez v. Switzerland, ECtHR 26 November 2013, no. 1785/08; Biao v. Denmark, ECtHR 25 March 2014, no. 38590/10; M.P.E.V. and Others v. Switzerland, ECtHR 8 July 2014, no. 3910/13. For freedom of expression, see e.g. Martin and Others v. France, ECtHR 12 April 2012, no. 30002/08; Tanasoaica v. Romania, ECtHR 19 June 2012, no. 3490/03; Krone Verlag GmbH v. Austria, ECtHR 19 June 2012, no. 27306/07; Martin Kostov v. Bulgaria, ECtHR 24 July 2012, no. 13801/ 07; Łopuch v. Poland, ECtHR 24 July 2012, no. 43587/09; Falter Zeitschriften GmbH v. Austria (No. 2), ECtHR 18 September 2012, no. 3084/07; Smolorz v. Poland, ECtHR 16 October 2012, no. 17446/07; Karpetas v. Greece, ECtHR 30 October 2012, no. 6086/10; Novaya Gazeta and Borodyanskiy v. Russia, ECtHR 28 March 2013, no. 14087/08; Reznik v. Russia, ECtHR 4 April 2013, no. 4977/05; Saint-Paul Luxembourg S.A. v. Luxemburg, ECtHR 18 April 2013, no. 26419/10; OOO 'Vesti' and Udkhov v. Russia, ECtHR 30 May 2013, no. 21724/03; Morice v. France, ECtHR 11 July 2013, no. 29369/10; Stojanovic v. Croatia, ECtHR 19 September 2013, no. 23160/09; Belpietro v. Italy, ECtHR 24 September 2013, no. 43612/10; Print Zeitungsverlag GmbH v. Austria, ECtHR 10 October 2013, no. 26547/07; Ristamäki and Korvola v. Finland, ECtHR 29 October 2013, no. 66456/09; De Lesquen du Plessis-Casso v. France (No. 2), ECtHR 30 January 2014, no. 34400/10; Dilipak and Karakaya v. Turkey, ECtHR 4 March 2014, nos. 7942/05 and 24838/05; Brosa v. Germany, ECtHR 17 April 2014, no. 5709/09; A.B. v. Switzerland, ECtHR 1 July 2014, no. 56925/08; Erla Hlynsdottir v. Iceland (No. 2), ECtHR 21 October 2014, no. 54125/10. For property cases, see e.g. Dimitru and Others v. Romania, ECtHR 4 September 2012 (dec.), no. 57265/08; Pyrantiene v. Lithuania, ECtHR 12 November 2013, no. 45092/07; Vikentijevik v. FYR Macedonia, ECtHR 6 February 2014, no. 27853/09. For family law cases, see e.g. B. v. Belgium, ECtHR 10 July 2012, no. $4320 / 11$.

154 See e.g. Karabadze and Others v. Georgia, ECtHR 2 October 2012, no. 1484/07; Gün and Others v. Turkey, ECtHR 18 June 2013, no. 8029/07; Kudrevecius and Others v. Lithuania, ECtHR 26 November 2013, no. 37553/05.

155 See Gerards, supra n. 121 and Smet, supra n. 121. 
may not regard this as problematic, since what counts is whether the conclusion of each particular judgment is sufficiently underpinned by the arguments provided. Whether these arguments are procedural or substantive in nature may depend on coincidence or preference, rather than on a well-considered policy of judicial argumentation. ${ }^{156}$

\subsection{Conclusions}

The analysis of the Court's case law presented in this chapter clearly witnesses to the importance of procedural elements and procedural review for its case law. The Court often attaches value to procedural fairness in relation to both the legislative process and judicial and administrative decision-making on the domestic level. It has set a variety of procedural requirements, the disobedience of which may give rise to the finding of a Convention violation of its own. Particularly interesting to the procedural turn taken in the Court's case law are the obligations to allow for individualised decision-making and for the domestic courts to apply the standards and criteria developed in the Court's case law. Also of importance is the value the Court attaches to the quality of national legislative procedures, where equal representation and participation, transparency and deliberation play an important role, and national stakeholders and civil society must be involved in fundamental rights debates.

In parallel with the case law establishing these requirements, the Court has developed several lines of case law in which it draws the consequences from the national authorities' compliance with these requirements. It has been shown that procedural-type review is visible both in relation to legislation and in relation to administrative and judicial decisions. Especially in cases concerning moral dilemmas, conflicts of rights and socio-economic matters, the Court tends to attach importance to the quality of the national decision-making, both in relation to legislation and in relation to national judgments. Where national judicial and administrative decisions are concerned, the Court mainly relies on procedural arguments in standard cases for which it has already developed easy-to-use standards and criteria for review. In these situation types, the Court may attach both negative and positive value to the quality of the decision-making process. To this extent, thus, a typology indeed can be provided for.

156 Ibid. 
Importantly, the analysis also reveals that in hardly any of these cases are the arguments from procedure decisive. Mostly they are only supportive, and they form part of a 'net' of arguments that, taken in their entirety, support the outcome reached by the Court. ${ }^{157}$ The main variation seems to be in whether the Court takes procedural arguments into account at all, and how much supportive value the argument has. It seems impossible to find a rational explanation for the Court's choice to either rely on procedural arguments, to a greater or lesser degree, or to leave them completely out of consideration. Sometimes the reason for not considering procedural arguments can be that the Court wants to redefine its substantive standards for review; then, indeed, procedural arguments have no real place in the Court's reasoning. In other cases, it may be that it has not obtained sufficient information by the parties about the national procedures in order to allow it to base its judgment on procedural arguments. And in yet other cases, it may simply be that the judges prefer a substantive approach over a more procedural one for reasons of their own.

In by far the most cases, thus, it seems that the Court relies on a 'pick and choose' approach, selecting those arguments that it considers useful in reasoning its judgment. These arguments may be of a procedural nature, for instance, if a procedural flaw or quality is particularly striking, but just as easily, they may not. These conclusions may not come as a surprise for close observers of the Court's case law. A 'bric-a-brac' approach is typical for the Court's argumentative style and, in fact, it is hardly to be expected that the Court would suddenly start relying on a highly structured and dogmatic argumentative approach that would clearly stipulate in which types of cases it will rely on procedural arguments and which value it will attach to such arguments.

Yet, the Court may be criticised for the lack of clarity and consistency that is disclosed by its use of procedural arguments in its reasonable review. National authorities are offered little guidance by this case law, as they can hardly know in advance how the Court will go about reviewing decisions taken by the legislature or by national courts. For that reason, it may be useful for the Court to build on the potential and possibilities offered by its case law on procedural review, applying the review more consistently in the types of cases set out above and drawing clearer consequences from procedural findings. Of course, such a more consistent approach can be hazardous, given the type of criticism that is

157 Smet, supra n. 121. 
possible of procedural review, and which is set out more clearly in other chapters of the current volume. ${ }^{158}$ Nonetheless, building on techniques and possibilities developed in other legal systems and in theoretical literature, as also further examined in this volume, it must certainly be possible to improve the Court's use of procedural arguments and to enable for finding a more fully developed typology in the future.

158 See in particular Chapter 7 of this volume by Angelika Nussberger: 'Procedural Review by the European Court of Human Rights: View from the Court'. 